\title{
PERUBAHAN RESPON TIONGKOK TERHADAP UJI COBA NUKLIR KOREA UTARA (2013-2018)
}

\author{
Renny Miryanti, Gita Talia Pridarita
}

\begin{abstract}
This paper aims to analyze about China's change of response toward North Korea's nuclear test. In this paper, there are three important points of discussion. The first discussion will be explained about the beginning and the progress of China and North Korea's relations. The second discussion is about China's response toward North Korea's nuclear test under Hu Jintao's leadership. The last discussion is about how and why the response of China toward North Korea nuclear program changed under Xi Jinping's leadership. This paper uses qualitative method with the secondary data, and use the Foreign Policy Making Theory with the Bilateral Relations concept to the research of those discussion. The result of this analysis shows that there four determinants that influence China's change of response toward North Korea's nuclear test, they are international context, decision maker, domestic politics, and economy and military condition.
\end{abstract}

Keywords: China, Foreign Policy, North Korea, Nuclear, Response

\section{PENDAHULUAN}

Hubungan bilateral dan kerjasama antara Tiongkok dan Korea Utara dimulai sejak tahun 1949, yang dilatarbelakangi dengan kedekatan letak geografis serta kesamaan ideologi komunis. Pada tahun 1950, Tiongkok juga banyak memberikan dukungan serta bantuan ketika Perang Korea terjadi antara Korea Utara dan Korea Selatan (Hong, 2014: 285). Pasca kematian Pemimpin Korea Utara, Kim Il Sung pada tahun 1994, Tiongkok semakin meningkatkan bantuan dan kerja samanya dengan Korea Utara untuk menjaga stabilitas negara tersebut. Bantuan dan kerjasama ini terus berlanjut hingga tahun 2003, dimana Tiongkok memberikan bantuan berupa biji-bijian makanan dan bahan bakar dalam jumlah yang 
sangat besar setiap tahunnya (Sutter, 2007: 158-164). Kerjasama inilah yang kemudian membuat hubungan bilateral antara Tiongkok dan Korea Utara menjadi semakin erat.

Pada tahun 2005 dan 2006, hubungan Tiongkok dan Korea Utara semakin dekat dengan adanya peningkatan dalam hubungan dagang dan investasi antara kedua negara (Hong, 2014: 294), akan tetapi, akhir tahun 2006 hubungan bilateral ini mengalami kemunduran, setelah Korea Utara melaksanakan uji coba nuklir pertamanya. Sebenarnya program nuklir Korea Utara ini telah ada sejak tahun 1965 ketika Korea utara membangun reaktor nuklir yang bertujuan untuk penelitian di Yongbyeon, Korea Utara (KBS World Radio, 2017a). Namun, pada tahun 1990-an mulai terjadi krisis nuklir ketika Korea Utara menolak dilakukannya inspeksi terhadap program nuklirnya. Tiongkok kemudian menginisiasi upaya negosiasi dalam Six Party Talks pada tahun 2002 (Liang, 2018). Walaupun negosiasi dalam Six Party Talks ini berjalan dengan cukup baik, namun tidak banyak mengubah perilaku Pemerintah Korea Utara yang tetap bersikeras untuk melanjutkan program nuklirnya hingga melakukan uji coba nuklir tersebut.

Dewan Keamanan Perserikatan Bangsa-Bangsa (DK-PBB) kemudian mengeluarkan Resolusi 1718 sebagai sanksi atas uji coba nuklir tersebut, yang isinya adalah larangan uji coba nuklir dan rudal, serta pemberlakuan embargo produk militer jenis apapun (Tempo, 2017a). Pada tahun 2009, Korea Utara melaksanakan uji coba nuklirnya yang kedua, yang lalu dilanjutkan dengan uji coba nuklir ketiganya pada tahun 2013. Pada tahun 2013 inilah sikap Tiongkok terlihat mulai berubah dengan melarang ekspor barang-barang yang dapat digunakan untuk membuat misil atau nuklir, serta senjata kimia dan biologis ke Korea Utara (BBC, 2018). Namun, sanksi-sanksi tersebut tidak membuat Korea Utara jera untuk melanjutkan program nuklirnya. Korea Utara kembali 
melaksanakan uji coba nuklirnya pada Januari 2016 dan September 2016.

Uji coba nuklir yang dilakukan oleh Korea Utara ini memunculkan berbagai kecaman dari masyarakat internasional karena dirasa mengganggu ketentraman negara-negara lain di sekitarnya, terutama pasca dilakukannya uji coba nuklir keenam pada September 2017. Pada tanggal 11 September 2017, Dewan Keamanan PBB mulai memberlakukan Resolusi 2375 yang merupakan sanksi baru bagi Korea Utara, resolusi ini berisi mengenai pembatasan-pembatasan ekspor beberapa komoditas ke Korea Utara (KBS World Radio, 2017b). Berbagai sanksi serta kecaman terhadap Korea Utara ini sama sekali tidak dihiraukan oleh pemerintah negara tersebut. Salah satu langkah yang dilakukan oleh Tiongkok untuk menunjukkan ketidaksetujuan terhadap program uji coba nuklir Korea Utara ini adalah dengan menjaga jarak dalam hubungan bilateral keduanya.

Perubahan yang terlihat sangat kentara adalah pasca uji coba nuklir keenam, dimana Tiongkok menerapkan sanksi dagang terhadap Korea Utara dengan membatasi gas alam cair dan pasokan Bahan Bakar Minyak atau BBM (BBC Indonesia, 2017). Padahal sejak bertahun-tahun berjalannya kerjasama antara Tiongkok dan Korea Utara, Tiongkok sangat mendukung dan selalu berupaya meningkatkan perekonomiannya sekaligus perekonomian Korea Utara melalui perdagangan dan kerjasama ekonomi lainnya. Perubahan respon Tiongkok terhadap Korea Utara ini mulai terjadi ketika terjadi pergantian kekuasaan dari Presiden $\mathrm{Hu}$ Jintao menjadi Presiden Xi Jinping di Tiongkok. Oleh karena itu, peneliti dalam hal ini berupaya untuk menjelaskan faktor-faktor apa saja yang mempengaruhi perubahan respon Tiongkok terhadap uji coba nuklir Korea Utara pada tahun 2013 hingga 2018.

\section{PEMBAHASAN}


Tiongkok dan Korea Utara mulai menjalankan kerjasama karena adanya latar belakang kesamaan ideologi komunis serta kedekatan wilayah geografis. Kedua negara saling bertukar pengakuan diplomatik pada 6 Oktober 1949, yang menjadi titik awal hubungan bilateral antara Tiongkok dan Korea Utara (Hasan, 2017). Hubungan Tiongkok dan Korea Utara semakin erat ketika terjadinya Perang Korea pada tahun 1950 hingga 1953, dimana Tiongkok mendukung dan banyak membantu Korea Utara selama perang berlangsung. Berdasarkan data statistik yang dikumpulkan oleh rumah sakit dan departemen kesehatan tentara di Tiongkok, dari total 2,97 juta tentara Tiongkok yang berperang dalam Perang Korea, 113.084 orang meninggal dalam peperangan, 25.621 tentara dinyatakan hilang, dan sekitar 70.000 korban meninggal akibat luka tembak, penyakit dan penyebab lainnya (China Daily, 2010).

Berbagai bantuan dan dukungan yang dilakukan Tiongkok di bawah kepemimpinan Mao Zedong kala itu, didasarkan pada kekhawatiran Pemerintah Tiongkok akan kemungkinan terjadinya kemunduran ekonomi dan kesulitan dalam menjalankan strategi-strategi dalam negeri yang hendak dikembangkan Tiongkok, apabila peperangan terus berlangsung (Glaser, 2009: 5). Ketika perang masih berlangsung, Korea Utara juga memulai program nuklirnya pada Desember 1952, dimana Korea Utara membentuk Atomic Research Institute dan Academy of Sciences (Nuclear Threat Initiative, 2018). Saat itu, Korea Utara bekerjasama dengan Uni Soviet untuk menjalankan program nuklir, karena Uni Soviet pun mempertimbangkan untuk memberikan bantuan sumber daya persenjataan kepada Korea Utara saat Perang Korea terjadi. Hal ini membuat Korea Utara semakin merasa membutuhkan nuklir untuk menyelesaikan peperangan (Kumparan News, 2018), namun program nuklir tersebut masih dalam proses kesepakatan, sehingga belum bisa dijalankan pada saat itu.

Pasca berakhirnya Perang Korea pada tahun 1953, stabilitas di Korea Utara menjadi terganggu. Berbagai infrastruktur dan lahan mengalami 
kerusakan, sehingga sulit untuk melakukan produksi dalam negeri. Hal ini pun mendorong Tiongkok untuk memberikan bantuan bersama dengan Uni Soviet terhadap Korea Utara. Beberapa bentuk bantuan ini diantaranya tenaga kerja, bahan baku, bahan rekonstruksi dan bangunan, transfer teknologi, serta pendidikan bagi para ahli dan siswa (Shen dan Xia, 2012: 3). Pada tahun 1956, Korea Utara melaksanakan penandatanganan piagam Joint Institute for Nuclear Research milik Uni Soviet, dimana pada saat itu Korea Utara juga mulai mengirim ilmuwan dan teknisi untuk mengikuti pelatihan. Korea Utara dan Uni Soviet juga membuat perjanjian tentang penggunaan energi nuklir secara damai pada tahun 1959 (Nuclear Threat Initiative, 2018). Kemudian, pada tahun 1961 Tiongkok dan Korea Utara menandatangani suatu perjanjian kerja sama yakni Sino - North Korean Mutual Aid and Cooperation Friendship Treaty. Perjanjian ini berisi kesepakatan untuk memperkuat aliansi pertahanan, menjalankan kerjasama dalam bidang ekonomi, budaya dan ilmu pengetahuan, serta saling menghormati dan tidak mencampuri urusan dalam negeri satu sama lain (Fitria, 2010).

Pada tahun 1990-an, kondisi hubungan bilateral antara Tiongkok dan Korea Utara mulai mengalami kemunduran. Di tengah hubungan Tiongkok dan Korea Utara yang mengalami kemunduran ini, isu program nuklir Korea Utara justru semakin menyebar. Isu ini membuat George H.W Bush yang pada saat itu memimpin Amerika, mengumumkan bahwa mereka akan menarik kembali senjata nuklirnya dari Korea Selatan. Hal ini pun akhirnya mengarah pada penandatanganan Joint Declaration kedua Korea, yang berisi perjanjian untuk tidak melakukan uji coba, memproduksi, menerima, memiliki, menyimpan, menyebarkan maupun menggunakan senjata nuklir (Nuclear Threat Initiative, 2018). Namun, pada tahun 1993 mulai terjadi krisis nuklir ketika Korea Utara bersikeras tidak mengijinkan International Atomic Energy Agency (IAEA) untuk melakukan inspeksi di salah satu lokasi nuklir Korea Utara. Hal ini pun 
menimbulkan kecurigaan negara-negara lainnya terhadap program nuklir Korea Utara.

Amerika Serikat kemudian mulai mengambil langkah untuk membuat kesepakatan dengan Pemerintah Korea Utara terkait isu program nuklir pada tahun 1994. Korea Utara dan Amerika menandatangani kesepakatan yang disebut dengan Agreed Framework, terkait persetujuan Korea Utara untuk membekukan program reaktor nuklirnya serta kembali menggunakan sumber energi berupa fosil, dan berjanji untuk mematuhi kewajiban IAEA (Tempo, 2017b). Di samping menghadapi permasalahan nuklir ini, Korea Utara juga mulai mencoba untuk memperbaiki hubungannya dengan Tiongkok pada tahun 1998, untuk bisa melaksanakan kerja sama ekonomi dengan baik. Hal ini bertujuan untuk mengembalikan stabilitas Korea Utara melalui peningkatan ekonomi agar dapat menjadi negara yang kuat dan sejahtera (Hong, 2014: 292). Peningkatan hubungan keduanya mulai tampak semakin baik ketika pada tahun 2000 Kim Jong Il, Presiden Korea Utara mengunjungi Beijing, dan kunjungan ke Shanghai pada tahun 2002 dalam rangka memperbaiki hubungan kedua negara tersebut (Hong, 2014: 292).

Konsistensi Tiongkok dalam membantu proses rekonstruksi Korea Utara pasca Perang Korea hingga kerjasama keduanya yang bertahan selama bertahun-tahun meskipun sempat mengalami kemunduran, menunjukkan bahwa Tiongkok memiliki tujuan untuk melebarkan pengaruhnya terhadap Korea Utara. Dengan adanya kesamaan ideologi dan kedekatan geografis, menjadi faktor yang turut membantu Tiongkok untuk bisa lebih dekat dengan Korea Utara. Hubungan bilateral kedua negara ini juga secara tidak langsung membuat Korea Utara menjadi tergantung kepada Tiongkok dalam mengandalkan bantuan dan kerjasama. Ketika terjadi perubahan sistem internasional pasca Perang Dingin, orientasi kebijakan luar negeri Tiongkok tampaknya mengalami 
sedikit perubahan, karena adanya normalisasi hubungan antara Tiongkok dengan Korea Selatan.

Dengan kata lain, hubungan aliansi tradisional Tiongkok dan Korea Utara mulai memudar dan lebih mengarah pada kerjasama strategis. Adanya perubahan dalam kebijakan Tiongkok ini memungkinkan Pemerintah Tiongkok untuk lebih memprioritaskan perhatiannya terhadap denuklirisasi Korea Utara, dan mencegah terjadinya efek domino dari program nuklir tersebut yang mungkin terjadi di kawasan Asia Timur. Akan tetapi, hubungan kerjasama strategis Tiongkok - Korea Utara yang baru berkembang ini, masih terdapat hubungan aliansi tradisional di dalamnya. Hal ini karena terkadang kebijakan kedua negara tersebut didorong oleh hubungan aliansi lama mereka, namun di saat tertentu kebijakan tersebut juga dipengaruhi adanya hubungan kerjasama strategis, sehingga hal ini pun menyebabkan terjadinya ambiguitas (Hochul, 2014: 102).

Ambiguitas ini yang kemudian mengarah pada kebijakan Tiongkok yang terkesan tidak menentu dan tidak dapat diprediksi. Hal ini karena Tiongkok masih mempertahankan stabilitas Korea Utara dan menghindari keruntuhan rezim pasca meninggalnya Kim Il Sung pada tahun 1994. Namun di sisi lain, Tiongkok juga turut serta dalam upaya mewujudkan denuklirisasi bersama negara lainnya. Oleh karena itu, terjadilah ambiguitas dalam arah kebijakan Tiongkok terhadap Korea Utara yang belum bisa melepas nilai-nilai ideologi bersama. Selain itu, Tiongkok jadi cenderung bersikap acuh tak acuh dalam mencapai denuklirisasi Korea Utara, karena adanya kekhawatiran akan ketidakstabilan yang mungkin terjadi apabila hal tersebut terwujud.

\section{Respon Tiongkok Terhadap Uji Coba Nuklir Korea Utara Pada Masa Kepemimpinan Hu Jintao}

Pada tahun 2003, mulai dibentuk suatu forum negosiasi untuk menyelesaikan permasalahan isu nuklir Korea Utara yakni Six Party 
Talks. Six Party Talks merupakan rangkaian negosiasi multilateral yang dimulai pada tahun 2003 dan dihadiri oleh Tiongkok, Jepang, Korea Utara, Rusia, Korea Selatan serta Amerika Serikat. Perundingan ini bertujuan untuk mencari resolusi terbaik terkait program nuklir Korea Utara. Perundingan ini diadakan di Beijing dengan diketuai oleh Tiongkok (Liang, 2018). Hal ini menunjukkan adanya peran yang lebih aktif dari Pemerintah Tiongkok dalam mengatasi persoalan program nuklir Korea Utara pada masa kepemimpinan Hu Jintao di Tiongkok.

Perundingan ini berjalan dengan cukup baik hingga tahun 2007. Dalam perundingan tersebut, para anggota membahas terkait upayaupaya untuk menghentikan program nuklir Korea Utara. Namun, meskipun telah diadakan Six Party Talks untuk membujuk Korea Utara agar meninggalkan program nuklirnya, pada akhirnya Korea Utara justru malah melakukan uji coba nuklir pada tahun 2006. Dalam hal ini, Six Party Talks gagal untuk mencegah program nuklir Korea agar tidak semakin berdampak buruk pada keamanan regional, bahkan internasional. Selama berjalannya perundingan Six Party Talks, kerjasama antara Tiongkok dan Korea Utara masih berjalan cukup baik. Hal ini ditunjukkan dengan adanya kunjungan satu sama lain yang dilakukan oleh Kim Jong Il dan Hu Jintao pada tahun 2004 hingga 2006 (Sutter, 2007: 171).

Hubungan kerjasama yang baik antara keduanya bukan berarti bahwa Tiongkok tidak peduli terkait uji coba nuklir yang telah dilakukan oleh Korea Utara. Tiongkok kecewa dengan tindakan Korea Utara yang dianggapnya sangat provokatif dan membahayakan keamanan kawasan Asia Timur. Selain itu, Six Party Talks juga mulai mengalami kemunduran pada tahun 2008 ketika Korea Utara kembali menolak dilakukannya inspeksi. Pada tahun 2009, Korea Utara menarik diri dari Six Party Talks, pasca DK PBB mengecam peluncuran roket jarak jauh yang dilakukan 
oleh Korea Utara (Chhor, 2017). Begitu pula pasca uji coba nuklir pertama Korea Utara, DK PBB menerapkan Resolusi 1718.

Resolusi 1718 ini berisi mengenai pelarangan uji coba nuklir dan rudal balistik bagi Korea Utara, serta perintah untuk meninggalkan semua persenjataan dan program nuklirnya. PBB juga menekankan sanksi ekonomi terhadap Korea Utara berupa larangan ekspor dan impor produk militer Korea Utara (Tempo, 2017a). Ketika resolusi tersebut dikeluarkan, Tiongkok menyetujuinya dengan syarat resolusi tersebut tidak mengarah pada aksi militer, tidak menyetujui pemeriksaan kargo, serta menolak menghentikan bantuan bahan bakar dan kebutuhan sehari-hari ke Korea Utara (Deutsche Welle, 2006). Tiongkok sebagai rekan kerjasama Korea Utara merasa kecewa dengan tindakan yang dilakukan oleh Korea Utara, namun di sisi lain Tiongkok tidak ingin sanksi yang diterapkan terhadap Korea Utara dapat mengganggu stabilitas pemerintahan negara tersebut.

Dalam situasi tersebut, Tiongkok juga mendapat tekanan dari beberapa negara, seperti Amerika dan Jepang yang melihat kedekatan Tiongkok dan Korea Utara sebagai peluang untuk membuat Tiongkok menggunakan pengaruhnya terhadap Korea Utara. Akan tetapi, dalam merespon sikap Korea Utara, Tiongkok memiliki beberapa pertimbangan (Zhang, 2009). Pertama, Tiongkok merasa bahwa masalah krisis nuklir ini secara khusus merupakan persoalan antara Amerika dan Korea Utara. Dan yang kedua, Tiongkok juga mempertimbangkan kekhawatirannya terkait runtuhnya rezim Kim Jong Il yang mungkin terjadi apabila Tiongkok ikut memberi tekanan terhadap Korea Utara. Kekhawatiran tersebut yakni, dapat terjadi ledakan pengungsi dari Korea Utara ke Tiongkok, yang kemudian memungkinkan masuknya pasukan Amerika Serikat ke perbatasan Tiongkok dalam situasi tersebut. Oleh karena itu, Tiongkok menyerukan agar semua pihak bisa menanggapi permasalahan nuklir Korea Utara secara tenang dan melalui dialog serta negosiasi (Zhang,

2009). 
Ketika pada tahun 2009 Korea Utara melaksanakan uji coba nuklir keduanya, Tiongkok mulai menunjukkan perubahan dalam menyikapinya. Tiongkok berperan sebagai mediator yang lebih aktif serta membangun citra nasional sebagai "responsible great power" dengan keberhasilannya dalam menyelenggarakan Six Party Talks. Hal ini menunjukkan bahwa Tiongkok mulai menanggulangi kebimbangan pertimbangannya terkait intervensi yang pada mulanya penuh keraguan di dalam permasalahan nuklir Korea Utara (Heungkyu, 2010: 2). Namun, di sisi lain ketika DK PBB menerapkan resolusi baru terhadap Korea Utara, Tiongkok menekankan agar penggunaan cara-cara diplomatik juga tetap diterapkan, dan sanksi - sanksi yang dibuat tidak mengganggu pembangunan negara maupun bantuan kemanusiaan Korea Utara (Huang, 2017).

Adanya keinginan untuk menjadi lebih aktif dalam dunia internasional, mendorong Tiongkok untuk kemudian mengubah strategi hubungannya dengan Korea Utara dan Korea Selatan. Tiongkok mengupayakan perubahan hubungannya dengan Korea Utara dari "hubungan khusus" menjadi "hubungan normal antarnegara", tanpa mengurangi sikapnya yang masih menghargai nilai strategis Korea Utara. Sedangkan hubungannya dengan Korea Selatan lebih mengarah pada "kemitraan kerja sama strategis" pada tahun 2008, guna membuka ruang politik untuk menangani permasalahan nuklir Korea Utara melalui perundingan bilateral Tiongkok - Korea Selatan (Heungkyu, 2010: 3).

Pada tanggal 11 Juli 2011, Hu Jintao dan Kim Jong Il berjanji untuk semakin memperkuat hubungan antara kedua negara bertepatan dengan peringatan 50 tahun Sino - North Korean Treaty of Friendship (Yonhap News, 2011 dalam Hong, 2014: 290). Ketika pada Desember 2011, Kim Jong Il meninggal dunia, Tiongkok membantu Korea Utara dalam mempertahankan stabilitas negaranya (Hong, 2014: 291). Oleh karena itu, Tiongkok masih melakukan kerjasama, terutama dalam perdagangan dan memberikan bantuan kepada Korea Utara dalam rangka menjaga 
kesejahteraan pemerintahan dan rakyat di Korea Utara. Hal ini juga tampaknya realisasi dari cita-cita Tiongkok untuk terus memperluas pengaruhnya terhadap Korea Utara sejak pada masa Pemerintahan Mao Zedong, sekaligus menghindari dampak buruk yang mungkin akan dirasakan Tiongkok apabila Korea Utara mengalami ketidakstabilan dalam pemerintahannya.

\section{Faktor Perubahan Respon Tiongkok terhadap Uji Coba Nuklir Korea Utara pada Masa Kepemimpinan Xi Jinping}

Respon Tiongkok terhadap uji coba nuklir Korea Utara mulai mengalami perubahan yang lebih signifikan pasca dilakukannya uji coba nuklir Korea Utara yang ketiga pada Februari 2013. Pasca uji coba nuklir tersebut, DK PBB kembali menerapkan resolusi terbaru, yakni Resolusi 2094 yang berisi mengenai penghentian transfer uang serta menutup Korea Utara dari sistem keuangan internasional (Tempo, 2017a). Jika sebelumnya Tiongkok menyetujui resolusi dari DK PBB dengan mengajukan beberapa syarat dan pengecualian, pada resolusi DK PBB terbaru pasca uji coba nuklir ketiga, sikap itu tak tampak lagi dari Tiongkok. Pada saat itu, Tiongkok juga sedang mengalami transisi kekuasaan dari $\mathrm{Hu}$ Jintao ke Xi Jinping yang mulai menjabat sebagai Presiden Tiongkok pada Maret 2013. Untuk mempermudah dalam melihat perubahan respon Tiongkok terhadap uji coba nuklir Korea Utara dari yang pertama hingga keenam ini, maka digunakan tabel perbandingan respon Tiongkok pada masa Pemerintahan $\mathrm{Hu}$ Jintao dan Xi Jinping sebagai berikut:

Tabel 1: Perbandingan Respon Tiongkok Terhadap Uji Coba Nuklir Korea Utara pada Masa Hu Jintao dan Xi Jinping

Respon Tiongkok pada Era Hu Jintao
Respon Tiongkok pada Era Xi

Jinping 


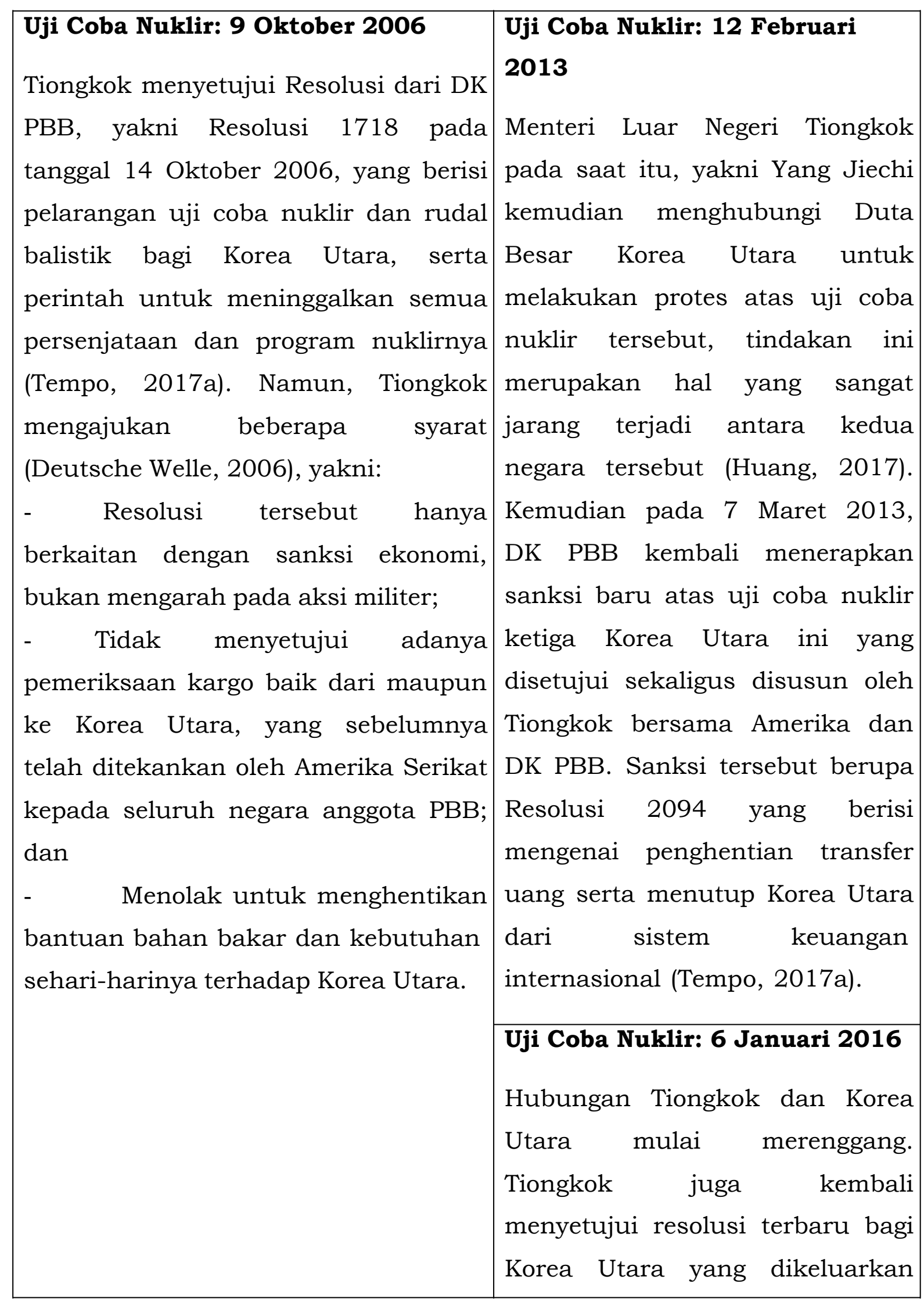




\begin{tabular}{|c|c|}
\hline & $\begin{array}{l}\text { pada } 2 \text { Maret } 2016 \text { oleh DK PBB, } \\
\text { yakni Resolusi } 2270 \text { (Tempo, } \\
2017 a \text { ), yang diantaranya berisi } \\
\text { embargo senjata; semua negara } \\
\text { diberikan wewenang untuk } \\
\text { memeriksa kargo dari dan ke } \\
\text { Korea Utara, baik yang dikirim } \\
\text { melalui laut maupun darat } \\
\text { secara paksa; melarang Korea } \\
\text { Utara untuk melakukan impor } \\
\text { berbagai produk yang dapat } \\
\text { digunakan untuk tujuan militer; } \\
\text { dan diplomat Korea Utara yang } \\
\text { melakukan kegiatan ilegal akan } \\
\text { dideportasi. }\end{array}$ \\
\hline $\begin{array}{l}\text { Uji Coba Nuklir: } 25 \text { Mei } 2009 \\
\text { Tiongkok menyetujui penerapan } \\
\text { Resolusi } 1874 \text { bagi Korea Utara dari } \\
\text { DK PBB, yang berisi sanksi ekonomi } \\
\text { dan komersial lebih lanjut, serta } \\
\text { desakan terhadap negara-negara } \\
\text { anggota PBB untuk melakukan } \\
\text { penggeledahan kargo Korea Utara } \\
\text { (Tempo, 2017a). Akan tetapi, Tiongkok } \\
\text { juga menekankan bahwa selain } \\
\text { penerapan sanksi dan resolusi, } \\
\text { diperlukan juga cara-cara diplomatik } \\
\text { dalam menghadapi permasalahan } \\
\text { tersebut. Adapun sanksi dan resolusi }\end{array}$ & $\begin{array}{l}\text { Uji Coba Nuklir: } 9 \text { September } \\
2016 \\
\text { Menteri Luar Negeri Tiongkok } \\
\text { menyatakan bahwa dalam } \\
\text { menghadapi uji coba nuklir Korea } \\
\text { Utara, semua pihak yang terlibat } \\
\text { hendaknya mengambil langkah- } \\
\text { langkah yang dapat memenuhi } \\
\text { kepentingan seluruh pihak, hal } \\
\text { ini karena apabila langkah yang } \\
\text { diambil hanya memberi } \\
\text { keuntungan bagi satu pihak, } \\
\text { maka sulit untuk menemukan } \\
\text { jalan keluar (Huang, 2017). }\end{array}$ \\
\hline
\end{tabular}




\begin{tabular}{|c|c|}
\hline $\begin{array}{l}\text { yang hendak diterapkan juga tidak } \\
\text { boleh memberi dampak buruk } \\
\text { terhadap pembangunan negara } \\
\text { maupun bantuan kemanusiaan di } \\
\text { Korea Utara sendiri. Tiongkok juga } \\
\text { memperingatkan agar tidak ada } \\
\text { penggunaan kekerasan atau paksaan } \\
\text { dalam pemeriksaan kargo Korea Utara } \\
\text { (Huang, 2017). Selain itu, Tiongkok } \\
\text { juga mendesak Pemerintah Korea } \\
\text { Utara untuk } \\
\text { komitmennya terkait denuklirisasi, } \\
\text { menghentikan langkah-langkah yang } \\
\text { dapat memperburuk situasi, serta } \\
\text { kembali ke Six Party Talks (Zhang, } \\
\text { 2009). }\end{array}$ & 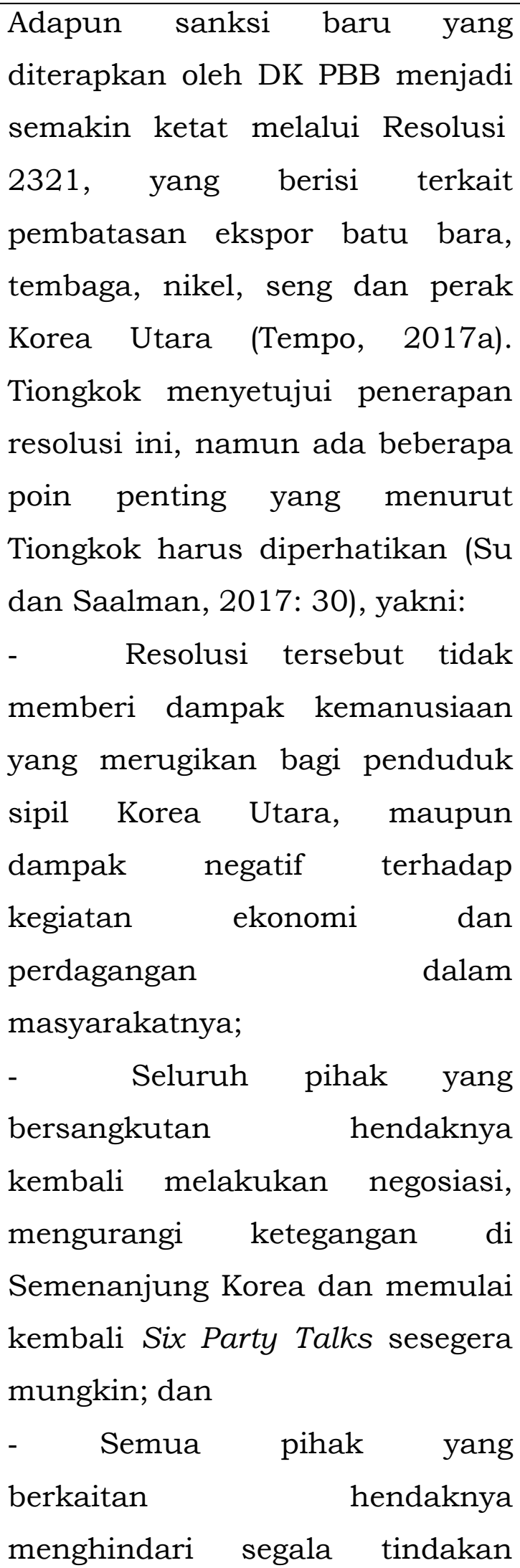 \\
\hline
\end{tabular}




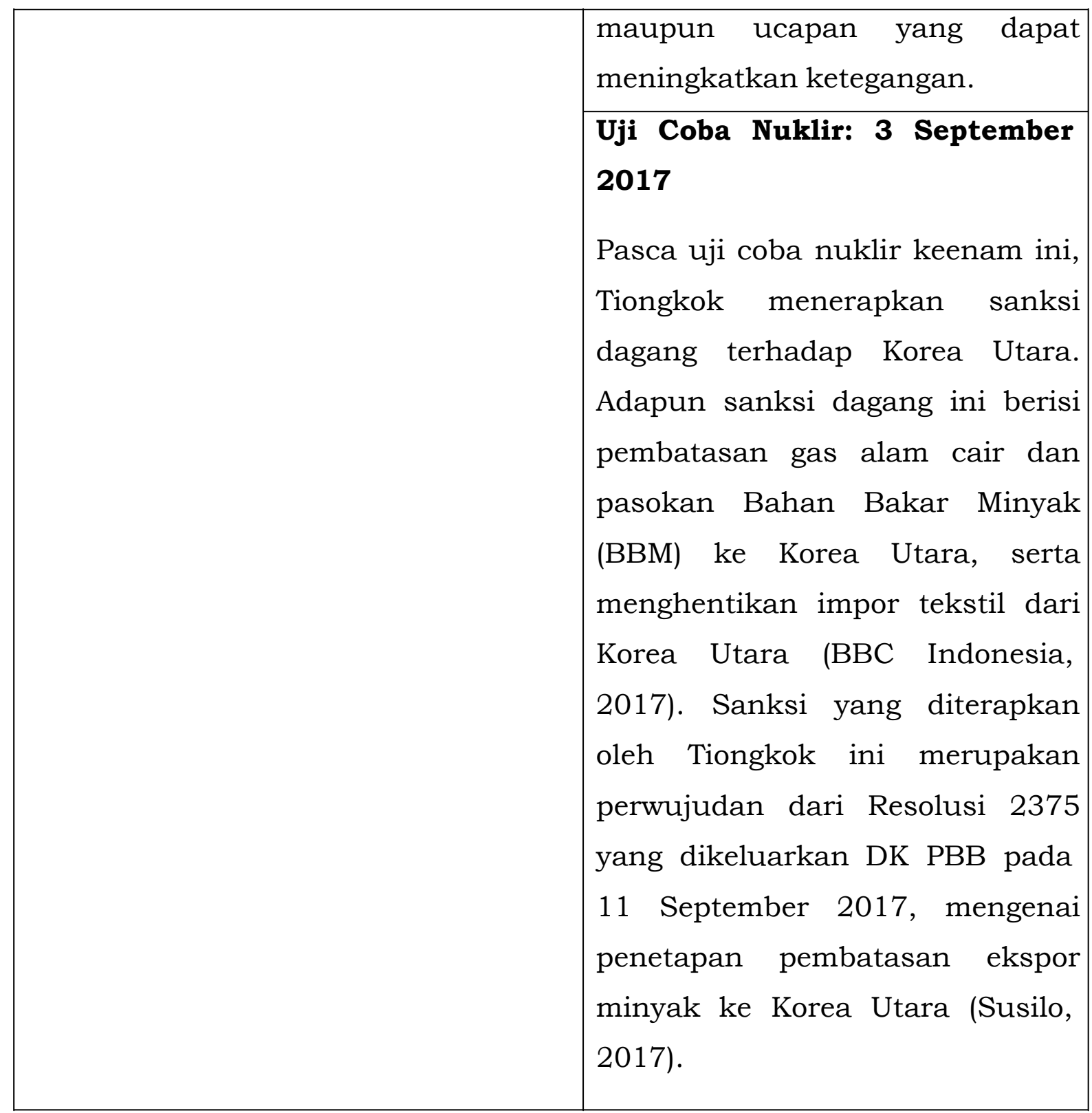

Sumber: Disarikan dari BBC Indonesia, 2017; Deutsche Welle, 2006; Huang, 2017; Su dan Saalman, 2017, hal 30; Susilo, 2017; Tempo, 2017a; dan Zhang, 2009.

Berdasarkan tabel tersebut, hubungan Tiongkok dan Korea Utara mulai merenggang sejak tahun 2016. Sebenarnya, pasca uji coba nuklir ketiga Korea Utara, Tiongkok mulai meningkatkan hubungan kerjasamanya dengan Korea Selatan dan mengakibatkan kerenggangan hubungan dengan Korea Utara selama tiga tahun hingga 2016. Kemudian 
pada September 2016 dan September 2017 Korea Utara melakukan uji coba nuklirnya yang kelima dan keenam. DK PBB juga mengeluarkan resolusi-resolusi pasca uji coba nuklir Korea Utara tersebut. Perubahan respon Tiongkok semakin jelas terlihat ketika Tiongkok menerapkan sanksi yang merupakan realisasi dari Resolusi 2375 yang merupakan sanksi terhadap uji coba nuklir keenam Korea Utara. Sanksi yang diterapkan oleh Tiongkok ini adalah pembatasan ekspor minyak ke Korea Utara (Susilo, 2017).

Pada era Pemerintahan Xi Jinping, hubungan Tiongkok dan Korea Utara cenderung menunjukkan hubungan kerjasama strategis melalui hubungan kerjasama normal antarnegara. Selain itu, Tiongkok juga mulai mengesampingkan hubungan aliansi tradisional yang terikat pada ideologi dan rasa persaudaraan (Sangsoo, 2016: 243). Perubahan sikap Tiongkok ini juga mengarah pada memburuknya hubungan bilateral Tiongkok dan Korea Utara. Hal ini disebabkan oleh Tiongkok yang bekerjasama dengan Amerika Serikat dalam menyusun dan mengadopsi Resolusi DK PBB 2094 (Hochul, 2014: 100). Selain menyusun dan mendukung resolusi DK PBB, Tiongkok juga mengupayakan untuk meningkatkan penegakan sanksi, mengurangi tingkat dan frekuensi kontak politik dengan Korea Utara, berusaha menjalankan kembali Six Party Talks, serta mengurangi bantuan politik terhadap kebijakan pembangunan ekonomi Korea Utara (Duchâtel dan Schell, 2013: 6).

Sebelum Tiongkok bekerjasama dengan Amerika dalam menghadapi isu nuklir Korea Utara, sebenarnya selama bertahun-tahun, Amerika telah mengajak masyarakat internasional untuk menerapkan sanksi dan hukuman tambahan terhadap Korea Utara. Hal ini dilakukan oleh Amerika karena negara tersebut menyadari sanksi DK PBB belum cukup untuk membuat Korea Utara jera dan menghentikan program nuklirnya. Selain itu, Amerika juga merasa tidak bisa mempengaruhi Korea Utara karena tidak memiliki hubungan ekonomi yang kuat dengan Korea Utara. Amerika pun menginisiasi sanksi sekunder dengan menyertakan pihak 
ketiga, yakni Tiongkok, untuk memperkuat langkah-langkah yang ada terhadap Korea Utara (Sangsoo, 2016: 251). Oleh karena itu, akhirnya Tiongkok pun melaksanakan kerjasama dengan Amerika dalam menghadapi permasalahan nuklir Korea Utara, dan mengubah kebijakan luar negerinya terhadap Korea Utara melalui perubahan responnya.

Konsep yang relevan untuk melihat hubungan antara Tiongkok dan Korea Utara dalam konteks ini adalah konsep hubungan bilateral. Hubungan bilateral merupakan suatu hubungan antara dua negara yang biasanya dilatarbelakangi dengan kepentingan dalam bidang politik, ekonomi serta budaya. Dalam hubungan bilateral, negara cenderung mengubah tujuan dan prioritasnya, tergantung pada kasus-kasus yang sedang terjadi atau urgensi situasional. Contohnya seperti, adanya sistem collective security atau keamanan kolektif yang diatur dalam Piagam PBB merupakan perjanjian yang dibentuk dalam hubungan multilateral. Sedangkan dalam hubungan bilateral, lebih dikenal istilah collective defense yang dibentuk karena adanya perlakuan istimewa dari negara yang lebih berkuasa (Tago, 2017: 2).

Tiongkok dan Korea Utara yang telah menjalin hubungan bilateral sejak tahun 1949, memiliki hubungan yang cukup stabil dari tahun ke tahun. Namun, ketika uji coba nuklir pertama Korea Utara terjadi, mulai terlihat perubahan dalam hubungan bilateral dan kerjasama kedua negara tersebut, sebagai respon dari Tiongkok yang tidak menyetujui program nuklir Korea Utara. Perubahan respon ini pun mempengaruhi hubungan bilateral kedua negara, karena adanya beberapa sanksi yang diterapkan Tiongkok terhadap Korea Utara dalam beberapa bidang kerjasama, terutama dalam bidang ekonomi yang kemudian memberi perubahan terhadap hubungan bilateral Tiongkok dan Korea Utara tersebut.

Proses pembuatan kebijakan sendiri memiliki beberapa tahapan, yakni penetapan situasi, pemilihan tujuan, pencarian alternatif, dan memilih alternatif. Proses-proses ini dilakukan dengan tujuan untuk 
memecahkan permasalahan yang dihadapi oleh seorang pengambil keputusan. Para pengambil keputusan memiliki peran dan tanggungjawab resmi dalam membuat suatu kebijakan luar negeri. Dalam praktiknya, para pengambil keputusan memutuskan suatu kebijakan dengan berdasarkan pada pemilihan tujuan politik luar negeri, karena kebijakan yang diambil berkaitan dengan kelangsungan hidup bangsa (Coplin, 1992: 38-40).

William D. Coplin mengasumsikan bahwa dalam proses pembuatan kebijakan luar negeri terdapat empat determinan yang mempengaruhinya, diantaranya yakni konteks internasional, pengambil keputusan, politik dalam negeri, serta kondisi militer dan ekonomi. Determinan konteks internasional berkaitan dengan tiga unsur penting, yaitu geografis, ekonomi dan politis. Ketiga unsur ini juga berkaitan dengan pengaruh yang diberikan negara lain yang dapat mengubah perilaku pengambil keputusan. Determinan pengambil keputusan, yakni berkaitan dengan kepribadian dan kepemimpinan para pemimpin negara selaku pengambil keputusan. Seorang pemimpin biasanya memiliki perilaku yang khas dalam membuat kebijakan luar negeri, namun juga dengan mempertimbangkan konteks internasional, dan kondisi-kondisi ekonomi serta militer yang dapat mempengaruhi kebijakan yang diambilnya tersebut (Coplin, 1992: 167-169).

Determinan politik dalam negeri menjelaskan mengenai perbedaan kebijakan luar negeri yang berdasarkan pada sistem politik di negara yang bersangkutan. Selain itu juga berkaitan dengan pertimbangan terhadap stabilitas politik dalam negeri. Terakhir, determinan kondisi ekonomi dan militer memiliki pengaruh yang cukup besar dalam pembuatan kebijakan uar negeri. Semakin mapan kondisi ekonomi dan militer suatu negara, biasanya akan membuat pengambil keputusan lebih berani dalam mengambil langkah dalam kebijakan luar negerinya (Coplin, 1992: 170172). Dalam melihat perubahan respon Tiongkok terhadap uji coba nuklir Korea Utara, penulis mencoba menjelaskan kebijakan luar negeri yang 
diambil oleh Xi Jinping selaku pemimpin negara Tiongkok dengan menganalisanya menggunakan empat determinan dalam pembuatan kebijakan luar negeri ini.

Melihat beberapa hal yang mempengaruhi perubahan respon Tiongkok terhadap uji coba nuklir Korea Utara ini, terdapat empat determinan dalam teori pembuatan kebijakan luar negeri Coplin yang berkaitan dengan pembahasan ini, yakni konteks internasional, pengambil keputusan, politik dalam negeri, serta kondisi ekonomi dan militer.

\section{Determinan pertama, Konteks Internasional}

Konteks internasional yang mempengaruhi perubahan respon Tiongkok terhadap uji coba nuklir Korea Utara adalah tekanan dari Amerika Serikat serta Six Party Talks yang sulit dilanjutkan. Amerika Serikat sebenarnya sudah sejak lama mengajak sekaligus menekan Tiongkok untuk mengubah kebijakannya terhadap Korea Utara agar negara tersebut segera mewujudkan denuklirisasi. Namun, tekanan dari Amerika Serikat semakin meningkat pasca dilakukannya uji coba nuklir Korea Utara yang keempat pada tahun 2016, dimana Tiongkok kemudian turut mengimplementasikan Resolusi 2270 dengan melakukan embargo beberapa produk terhadap Korea Utara (Sangsoo, 2016: 248). Kemudian pasca uji coba nuklir keenam di tahun 2017, Tiongkok bekerjasama dengan Amerika untuk mengerahkan pasukan maritim dengan tujuan melarang perdagangan ilegal dalam bentuk pengiriman barang melalui jalur laut yang kemungkinkan akan dilakukan oleh Korea Utara, karena semakin tingginya tekanan dari masyarakat internasional (Mata Mata Politik, 2018).

Salah satu hal yang membuat Tiongkok merasa bahwa Amerika semakin menekannya untuk melakukan perubahan kebijakan terhadap Korea Utara adalah adanya peningkatan latihan militer yang dilakukan oleh Amerika. Hal ini dilakukan Amerika untuk meningkatkan kerja sama 
pertahanan dengan Korea Selatan dan Jepang dengan cara menyebarkan Terminal High Altitude Area Defense (THAAD), yang merupakan alat untuk menghadang rudal balistik jarak pendek dan menengah yang jauhnya mencapai $200 \mathrm{~km}$ hingga $150 \mathrm{~km}$ dari ketinggian (Meick dan Salidjanova, 2017: 3). Adanya program THAAD ini membuat Tiongkok khawatir apabila digunakan metode militer dalam mengatasi permasalahan nuklir Korea Utara, dapat menyebabkan terjadinya peperangan maupun arm race di Kawasan Asia Timur, yang akhirnya dapat mempengaruhi kondisi dalam negeri Tiongkok.Namun di sisi lain, kedinamisan situasi kawasan Asia Timur tersebut menuntut suatu sikap dari Amerika untuk bertindak. Amerika memiliki kepentingan melindungi para sekutunya di Asia pasifik dan memastikan adanya stabilitas kawasan (Sari dan Yani, 2017: 13)

Dengan kata lain, Tiongkok tidak pernah menyetujui penggunaan militer dalam mewujudkan denuklirisasi Semenanjung Korea dan berupaya menghindarinya, karena tidak menginginkan terjadinya peperangan seperti yang pernah terjadi sebelumnya. Pertimbangan Amerika yang lebih menekankan penggunaan militer dalam penyelesaian masalah nuklir Korea Utara secara tidak langsung menjadi tekanan bagi Tiongkok untuk segera mengambil langkah pencegahan terjadinya perang di Semenanjung Korea. Hal ini bukan hanya untuk mencapai denuklirisasi di Semenanjung Korea, melainkan juga untuk mencegah penggunaan militer yang mungkin akan diambil oleh Amerika jika Korea Utara tidak juga menghentikan program nuklirnya. Dengan kata lain, perubahan kebijakan Tiongkok terhadap uji coba nuklir Korea Utara dipengaruhi oleh tekanan secara langsung dan tidak langsung dari Amerika Serikat.

Faktor konteks internasional yang kedua adalah sulitnya melanjutkan kembali perundingan melalui Six Party Talks. Pasca terjadinya kemunduran pada tahun 2008, Six Party Talks tidak pernah berjalan lagi. Hingga pada Januari 2011, Tiongkok mulai mengupayakan untuk melanjutkan kembali perundingan tersebut dengan mengusulkan 
tiga langkah perundingan. Langkah-langkah ini terdiri dari perundingan bilateral Korea Utara - Korea Selatan, perundingan bilateral Amerika Serikat - Korea Utara, kemudian Six Party Talks dengan melibatkan enam negara anggota sebelumnya. Namun, Kim Jong Un yang menggantikan Kim Jong Il, menyatakan penolakannya untuk mengambil langkah dalam upaya denuklirisasi, sehingga Six Party Talks pun gagal dilanjutkan kembali (Sangsoo, 2016: 250). Setelah perundingan ini tidak berhasil dilanjutkan, akhirnya hanya resolusi dari DK PBB yang diberlakukan terhadap Korea Utara.

Upaya Tiongkok untuk melanjutkan kembali Six Party Talks juga tampak dari pernyataan-pernyataan yang disampaikan oleh Menteri Luar Negeri Tiongkok, Wang Yi dalam beberapa kegiatan sepanjang tahun 2016. Seperti menyatakan bahwa tujuan utama Tiongkok untuk menyelesaikan program nuklir Korea Utara adalah dengan mengembalikan ke jalur negosiasi. Selain itu, Wang Yi juga menyatakan bahwa penggunaan sanksi dan tekanan merupakan hal yang tidak bertanggung jawab karena tidak memikirkan masa depan Semenanjung Korea ( $\mathrm{Ru}, 2016:$ 13). Dalam menanggapi seruan Tiongkok, Wakil Juru Bicara Kementerian Luar Negeri Jepang menyatakan bahwa pihak Jepang berpandangan bahwa dengan adanya sanksi baru dari DK PBB diperlukan juga "tekanan yang lebih efektif" dalam menghadapi Korea Utara agar segera mengambil langkah nyata dalam mencapai denuklirisasi, sehingga mereka berpendapat bahwa saat itu bukan waktu yang tepat untuk memulai kembali perundingan dalam Six Party Talks (Chhor, 2017). Selain itu, Alexander Matsegora yang merupakan Duta Besar Rusia untuk Korea Utara juga berpandangan bahwa sebelum melaksanakan Six Party Talks, tugas utama yang harus dilakukan adalah untuk mengurangi ketegangan hubungan antara Korea Utara dan Korea Selatan, serta Korea Utara dan Amerika

Serikat

(Tass,

2018). 
Hal ini akhirnya membuat Tiongkok mengubah kebijakan dan sikapnya terhadap Korea Utara, dengan tujuan untuk mencoba mencegah dan menghentikan uji coba nuklir yang mungkin hendak dilakukan kembali oleh Korea Utara. Kegagalan dalam mengajak negara-negara anggota Six Party Talks untuk melaksanakan perundingan, membuat Pemerintah Tiongkok merasa harus segera mengambil keputusan dan bertindak sendiri sesuai dengan keadaan yang sulit diprediksi.

\section{Determinan Kedua, Pengambil Keputusan}

Pasca uji coba nuklir ketiga Korea Utara, menjadi titik balik dalam hubungan bilateral Tiongkok dan Korea Utara. Tingkat kunjungan antara kedua negara yang mulai menurun, serta tidak pernah bertemunya kedua pemimpin negara semenjak Xi Jinping menjabat menjadi Presiden Tiongkok, memunculkan perdebatan mengenai kemungkinan perubahan kebijakan yang hendak diterapkan terhadap Korea Utara di bawah Pemerintahan Xi Jinping (Duchâtel dan Schell, 2013 dalam Su dan Saalman, 2017: 1). Menurut pendapat para ahli dan petinggi Tiongkok, terjadi perubahan pandangan terhadap Korea Utara menjadi 'strategic liability' dari yang awalnya merupakan 'strategic asset. Pandangan ini yang kemudian mengarah pada perdebatan terkait perubahan kebijakan, yang pada mulanya menjaga stabilitas Korea Utara menjadi denuklirisasi Korea Utara, serta dari hubungan khusus menjadi hubungan yang normal (Hochul, 2014: 104).

Tiongkok melihat Pemerintahan Korea Utara lebih stabil dalam beberapa tahun ini, hal ini membuat keterlibatan Tiongkok di Korea Utara tidak lagi terlalu dibutuhkan, jika dibandingkan dengan pada masa krisis pangan di Korea Utara di pertengahan 1990-an, serta pada saat terjadinya transisi kekuasaan tahun 2011 lalu (Sangsoo, 2016: 247). Berdasarkan latar belakang inilah, Tiongkok akhirnya mengubah kebijakan luar negerinya terhadap Korea Utara yang pada mulanya berdasarkan pada tiga prinsip utama yakni "no war, no instability and no nuclear weapons" 
dengan menekankan prinsip stabilitas, berubah menjadi "denuclearrization, peace and stability" serta menekankan dimulainya kembali Six Party Talks (Government of the People's Republic of China, 2013 dalam Su dan Saalman, 2017: 8).

Dalam prosesnya, Tiongkok tetap berharap agar perubahan kebijakannya ini tidak menimbulkan ketidakstabilan Korea Utara. Tiongkok masih khawatir akan dampak yang mungkin dirasakannya apabila stabilitas Korea Utara terganggu. Kemungkinan terkait Six Party Talks yang tidak dapat dilanjutkan dalam waktu dekat, membuat Tiongkok akhirnya mempertimbangkan cara lain dalam menemukan solusi untuk menghadapi permasalahan nuklir Korea Utara. Tiongkok kemudian berupaya untuk mencapai tujuan dan kepentingan yang saling bertentangan melalui mekanisme jalur ganda atau dual track mechanism (Tiejun dkk, 2016: 9).

Dual track mechanism ini dilakukan karena muncul dupleksitas dan ambiguitas ketika terjadi perdebatan antara para 'tradisionalis' dan 'strategis'. Tradisionalis memandang bahwa Tiongkok harus menjaga stabilitas rezim Korea Utara karena masih membutuhkannya sebagai buffer zone. Sedangkan Strategis memandang bahwa bahwa denuklirisasi Korea Utara lebih penting karena berorientasi pada kepentingan global (Hochul, 2014: 105 dan 108). Oleh karena itu, akhirnya Tiongkok mengambil 'jalan tengah' dalam mengubah responnya terhadap Korea Utara melalui dual track mechanism tersebut. Adapun jalan tengah yang diambil oleh Tiongkok ini berdasarkan pada empat norma kebijakan luar negeri Tiongkok, diantaranya yakni: 1) Tiongkok berfokus pada stabilitas; 2) Tiongkok menolak "penahanan", yakni menolak reunifikasi Korea untuk menghindari pengepungan politik yang mungkin direncanakan Amerika dan Jepang; 3) Permintaan Tiongkok untuk menghargai tatanan regional. Tiongkok mengusulkan agar Korea Utara menghentikan uji coba nuklirnya, dengan syarat latihan militer Amerika dan Korea Selatan harus 
dibekukan, untuk meningkatkan hubungan antar Korea yang berada di satu kawasan yang sama; serta 4) Tiongkok menginginkan hubungan timbal balik dengan negara tetangga (Easley, 2019).

\section{Determinan Ketiga, Politik Dalam Negeri.}

Pengambil keputusan politik luar negeri biasanya akan dihadapkan pada suatu kondisi yang mengharuskannya mengambil konsekuensi tertentu, guna menjaga stabilitas dalam negeri. Politik dalam negeri di sini berkaitan dengan kondisi domestik yang apabila terusik dengan permasalahan eksternal, maka dapat menimbulkan instabilitas dalam negeri yang akhirnya membuat keputusan luar negeri yang diambil menjadi lebih agresif (Coplin, 1992: 171). Dalam hal ini, determinan politik dalam negeri berkaitan dengan faktor pengambil keputusan pada pembahasan sebelumnya. $\mathrm{Xi}$ Jinping mengkhawatirkan adanya kemungkinan gangguan terhadap stabilitas negaranya, jika kepentingan nasionalnya sulit tercapai akibat terus dilaksanakannya uji coba nuklir Korea Utara.

Xi Jinping menunjukkan respon yang diplomatis terhadap uji coba nuklir Korea Utara ini. Respon yang diplomatis ini maksudnya adalah dimana Xi Jinping bisa menyeimbangkan antara kepentingannya dengan segala kemungkinan terburuk atau pertimbangan resiko yang akan diambil di kemudian hari melalui jalan tengah yang diambilnya. Kebimbangan terkait kepentingan yang bertentangan justru berhasil diubah menjadi mekanisme pemecahan masalah. Hingga akhirnya Tiongkok mewujudkan tujuannya melalui dual track mechanism, dimana pihaknya berupaya menjaga stabilitas Korea Utara dengan pertimbangan sanksi yang tidak terlalu beresiko. Namun di sisi lain, Tiongkok juga berusaha mewujudkan denuklirisasi dengan turut menerapkan sanksi, serta mengharapkan dengan tercapainya denuklirisasi maka stabilitas dan kepentingan nasional Tiongkok dapat tetap terjaga. 
Kondisi ekonomi dan militer suatu negara berkaitan erat dengan kemampuannya dalam menetapkan suatu kebijakan luar negeri tertentu. Dengan kata lain, kebijakan luar negeri yang diambil oleh pengambil keputusan di suatu negara harus mempertimbangan kemampuan yang dibutuhkan untuk mempertanggungjawabkan politik luar negerinya (Coplin, 1992: 172). Hal ini berkaitan dengan keputusan Tiongkok ketika mulai berperan lebih aktif dalam dunia internasional terkait permasalahan nuklir Korea Utara. Dengan turut menyusun salah satu Resolusi DK PBB serta menerapkan sanksi dagang terhadap Korea Utara, merupakan suatu keputusan besar yang dipertimbangkan dengan melihat kondisi ekonomi dan militer negaranya. Padahal perubahan respon yang dilakukan oleh Tiongkok ini dapat berakibat pada kemunduran ekonomi dan kemungkinan terjadinya permusuhan antara Tiongkok dan Korea Utara.

Sejak awal tahun 1990-an, Tiongkok telah menjadi pemasok utama makanan bagi Korea Utara dan telah menyumbang hampir 90\% dari impor energinya. Dalam hal ini, Tiongkok dapat memberikan pengaruh yang menentukan terhadap perilaku Korea Utara. Selain itu, dalam hal militer, Tiongkok merupakan salah satu kekuatan militer utama dunia yang ditandai dengan peringkat 2 dalam pengeluaran militer yang ditempatinya sejak tahun 2008. Tiongkok juga mengembangkan angkatan laut dan udaranya, serta meningkatkan pengeluaran bagi militernya, dengan tujuan untuk memperluas politik kekuasaannya di tingkat global, dimana $\mathrm{Xi}$ Jinping ingin mewujudkan "kebangkitan besar bangsa Tiongkok" (Sooeun, t.t). Oleh karena itu, perubahan respon Tiongkok dengan menggunakan sanksi ekonomi merupakan salah satu jalan dari cita-cita $\mathrm{Xi}$ Jinping untuk dapat menyebarkan pengaruhnya dan membangun citra nasionalnya di mata dunia.

\section{KESIMPULAN}


Perubahan respon Tiongkok terhadap uji coba nuklir Korea Utara dipengaruhi oleh keempat determinan dalam pembuatan kebijakan luar negeri Coplin, namun dua determinan yang paling dominan adalah konteks internasional dan pengambil keputusan. Faktor konteks internasional, yakni tekanan dari Amerika Serikat dan sulitnya melanjutkan Six Party Talks, serta faktor pengambil keputusan. Tekanan dari Amerika yang mulai menggunakan ancaman militer serta penekanan resolusi terhadap Korea Utara yang membuat Tiongkok merasa khawatir terkait masa depan di Semenanjung Korea dan negara-negara lain di kawasan Asia Timur. Sementara itu, sulitnya melanjutkan Six Party Talks sebagai wadah negosiasi penyelesaian isu nuklir Korea Utara untuk menghindari penggunaan sanksi maupun kekerasan sebagai solusi, membuat Tiongkok mengambil langkah untuk mengubah orientasi kebijakan luar negerinya guna menemukan jalan terbaik mencegah uji coba nuklir Korea Utara.

Faktor yang paling berpengaruh di antara keduanya adanya faktor pengambil keputusan. Perubahan kepemimpinan di Tiongkok yang mulai dipimpin oleh Xi Jinping pada tahun 2013, membuat Tiongkok bertindak lebih berani dan tegas terhadap Korea Utara. Hal ini dilakukan dengan pertimbangan Xi Jinping terhadap dua determinan lainnya, yakni faktor politik dalam negeri serta faktor kondisi ekonomi dan militer negaranya. Xi Jinping dapat melihat peluang untuk berdiplomasi dalam tindakan yang dilakukan Pemerintah Korea Utara di bawah pimpinan Kim Jong Un. $\mathrm{Xi}$ Jinping juga mampu mengubah tekanan internasional dari Amerika dan kesulitan melanjutkan Six Party Talks menjadi pertimbangan untuk mengubah orientasi kebijakan luar negerinya terhadap negara yang telah memiliki hubungan aliansi tradisional sejak masa Perang Korea tersebut, sesuai dengan tujuan dan kepentingan nasional yang hendak dicapainya. Sikap dan kemampuan ini yang membedakan Xi Jinping dengan pemimpin-pemimpin Tiongkok sebelumnya, dan membuat Tiongkok berhasil mengubah responnya melalui kebijakan terhadap Korea Utara. 


\section{DAFTAR PUSTAKA}

BBC Indonesia. 2017. Cina memberlakukan sanksi dagang terhadap Korea Utara. Diakses dari https://www.bbc.com/indonesia/dunia41370754 pada tanggal 29 Maret 2019.

BBC. 2018. North Korea profile - Timeline. Diakses dari https://www.bbc.com/news/world-asia-pacific-15278612 pada tanggal 30 Desember 2018.

Chhor, Khatya. 2017. France 24. China pushes for new six-party talks as N. Korea crisis enters 'critical' phase. Diakses dari https://www.france24.com/en/20170806-china-new-six-party- talksnorth-korea- nuclear-crisis-critical-un-sanctionspada tanggal 24 Mei 2019.

China Daily. 2010. 180,000 Chinese soldiers killed in Korean War. Diakses dari http://www.china.org.cn/china/201006/28/content_20365659.htm pada tanggal 12 Februari 2019.

Coplin, William D. 1992. Pengantar Politik Internasional: Suatu Telaah Teoritis. Sinar Baru: Bandung.

Deutsche Welle. 2006.Resolusi Keras PBB untuk Korea Utara Disahkan. Diakses dari https://www.dw.com/id/resolusi-keras-pbb-untukkorea-utara-disahkan/a- 2935205 pada tanggal 3 Januari 2019.

Duchâtel, M. dan Schell, P. 2013. China's Policy on North Korea: Economic Engagement and Nuclear Disarmament. SIPRI Policy Paper no. 40.4 Diakses dari http://books.sipri.org/product_info?c_product_id=470. Dikutip dalam: Su, Fei dan Saalman, Lora. 2017. China's Engagement of North Korea Challenges and Opportunities for Europe. Research, hal 1. Stockholm International Peace Research Institute.

Duchâtel, Mathieu dan Schell Phillip. 2013. China's Policy on North Korea Economic Engagement and Nuclear Disarmament. Research, hal 1-66. Stockholm International Peace Research Institute.

Easley, Leif-Eric. 2019. Washington Post. Why China takes a middle-of-theroad policy toward North Korea. Diakses dari https://www.washingtonpost.com/politics/2019/02/28/whychina-takes-middle- of-the-road-policy-toward-northkorea/?noredirect=on\&utm_term $=.072 \mathrm{fc} 322 \mathrm{bc} 70$ pada tanggal 2 Juli 2019. 
Fitria, Devi. 2010. Persepsi China tentang Korea Utara. Diakses dari https:/ / historia.id/politik/articles / persepsi-china-tentang-koreautara-6mxrP pada tanggal 10 Maret 2019.

Glaser, Bonnie S. 2009. China's Policy in the Wake of the Second DPRK Nuclear Test. Journal of China Security, 5 (2), hal 1-11.

Government of the People's Republic of China. 2013. Wang Yi Emphasizes Three Positions on Korean Peninsula Affairs. Diakses dari http: / / www.gov.cn/gzdt/2013-04/13/content_2377184.htm.

Dikutip dalam: Su, Fei dan Saalman, Lora. 2017. China's Engagement of North Korea Challenges and Opportunities for Europe. Research. Stockholm International Peace Research Institute. Hal 8.

Hasan, Rizki Akbar. 2017. Liputan 6. Hubungan China-Korut dari Sekutu Dekat Mengarah ke Seteru? Diakses dari https://www.liputan6.com/global/read/2941208/hubungan- chinakorut-dari-sekutu-dekat-mengarah-ke-seteru pada tanggal 12 Februari 2019.

Heungkyu, Kim. 2010. Evolving China's Foreign Policy in Northeast Asia under Hu Jintao's Leadership and Implications to Korea-China Relations. Paper, hal 1-10. Dipresentasikan di workshop Pusat Kebijakan Amerika - Korea oleh Professor Kim Heungkyu dari Institute of Foreign Affairs and National Security.

Hochul, Lee. 2014. Rising China and the Evolution of China-North Korea Relations. The Korean Journal of International Studies, vol.12, hal 99-111.

Hong, Sukhoon. 2014. What Does North Korea Want from China? Understanding Pyongyang's Policy Priorities toward Beijing. The Korean Journal of International Studies, 12 (1), hal 277-303.

Huang, Kristin. 2017. South China Morning Post. How China responded to previous North Korean nuclear tests. Diakses dari

https://www.scmp.com/news/china/diplomacydefence/article/2109692/how- china-responded-previous-northkorean-nuclear-tests pada tanggal 15 Maret 2019.

KBS World Radio. 2017a. Catatan tentang nuklir dan rudal Korea Utara. Diakses dari

http://world.kbs.co.kr/special/northkorea/contents/history/nucl eus_history.htm?1 ang=i\#his2010pada tanggal 9 Oktober 2017.

KBS World Radio. 2017b. Dewan Keamanan PBB Mengesahkan Resolusi Sanksi Baru Terhadap Korea Utara. Diakses dari 
http://world.kbs.co.kr/special/northkorea/contents/news/koreat oday_view.htm?N $\quad$ o=3038\&lang=i pada tanggal 15 Oktober 2017.

Liang, Xiaodon. 2018. The Six Party Talks at a Glance. Diakses dari https://www.armscontrol.org/factsheets/6partytalks pada tanggal 18 Desember 2018.

Mata Mata Politik. 2018. Angkatan Laut China Mampu Buat Sanksi Korea Utara Lebih 'Menggigit'. Diakses dari https://www.matamatapolitik.com/angkatan-laut- china-mampubuat-sanksi-korea-utara-lebih-menggigit/ pada tanggal 8 April 2019.

Meick, Ethan dan Salidjanova, Nargiza. 2017. China's Response to U.S.South Korean Missile Defense System Deployment and its Implications. Staff Research Report, 1-16. U.S.-China Economic and Security Review Commission.

Nuclear Threat Initiative. 2018. North Korea's Nuclear History. Diakses dari https://www.nti.org/learn/countries/north-korea/nuclear/ pada tanggal 3 Maret 2019.

Ru, Sun. 2016. Beijing And Pyongyang: A "Special Friendship" Facing The Final Curtain. Research, hal 1-15. Research. Institute for International Political Studies (ISPI).

Sangsoo, Lee. 2016. Xi Jinping's Foreign Policy toward North Korea. Orientaliska Studier Journal, no.148. NAJAKS Conference Stockholm University, Nordic Association of Japanese and Korean Studies.

Sari, Suwarti, dan Yani, Nyanyan Mochamad. 2017. Revitalisasi Hubungan Amerika Serikat di Asia Pasifik, Jurnal Dinamika Global2(02), 4-17.

Shen, Zhihua dan Xia, Yafeng. 2012. China and the Post-War Reconstruction of North Korea, 1953-1961. Working Paper, hal 192. Woodrow Wilson International Center for Scholars.

Sooeun, Yong. Tanpa tahun. Why is China important? Diakses dari https://www.futurelearn.com/courses/korea-globalcontext/0/steps/18341 pada tanggal 25 Juli 2019.

$\mathrm{Su}$, Fei dan Saalman, Lora. 2017. China's Engagement of North Korea Challenges and Opportunities for Europe. Research, hal 1-53. Stockholm International Peace Research Institute.

Susilo, Richard. 2017. Resolusi Dewan Keamanan PBB Sepakat tidak Memblokir Ekspor Minyak ke Korea Utara. Diakses dari http://www.tribunnews.com/internasional/2017/09/12/resolusi- 
dewan- keamanan-pbb-sepakat-tidak-memblokir-ekspor-minyak-kekorea-utara pada tanggal 27 Juni 2019.

Sutter, Robert. 2007. China's Foreign Policy toward North Korea-A US Perspective. International Journal of Korean Studies, 9 (2), hal 159181.

Tago, Atsushi. 2017. Multilateralism, Bilateralism, and Unilateralism in Foreign Policy. Journal and Oxford Research Encyclopedia of Politics. Oxford University Press USA. Hal 1-18.

Tass. 2018. Revival of six-party talks on North Korea unlikely now Russian ambassador. Diakses dari https://tass.com/politics/989032 pada tanggal 20 Juni 2019.

Tempo. 2017a. Berbagai Sanksi PBB untuk Korea Utara dalam 11 Tahun. Diakses dari https://dunia.tempo.co/read/910196/berbagaisanksi-pbb-untuk-korea-utara- dalam-11-tahun pada tanggal 30 Desember 2018.

Tempo. 2017b. Sejarah Program Senjata Nuklir Korea Utara. Diakses dari https://dunia.tempo.co/read/866883/sejarah-program-senjatanuklir-korea-utara pada tanggal 7 Maret 2019.

Tiejun, Yu, Yuanzhe, Ren dan Junsheng, Wang. 2016. Chinese Perspectives towards The Korean Peninsula in The Aftermath of North Korea's Fourth Nuclear Test. Stimson Center.

Yonhap News. 2011. China Hopes for 'Stability' after Jang's Execution. Diakses dari www.globalpost.com/dispatch/news/yonhapnewsagency/131213/china-hopes- stability-after-jangs-execution. Dikutip dalam: Hong, Sukhoon. 2014. What Does North Korea Want from China? Understanding Pyongyang's Policy Priorities toward Beijing. The Korean Journal of International Studies, 12 (1). $\quad \mathrm{Hal}$ 290.

Zaharia, Andreea Alina. 2016. United States, China and the North Korean Nuclear Program. Journal of Danubius University, 9 (1), hal 90-98.

Zhang, Hui. 2009. Bulletin of the Atomic Scientists. The North Korean Nuclear Test: The Chinese Reaction. Diakses dari https://thebulletin.org/2009/06/the-north- korean-nuclear-testthe-chinese-reaction/\#sf_form_salesforce_w21_lead_1 pada tanggal 15 Maret 2019. 